\title{
Beyond metaphor: archaeology as a social and artistic practice
}

\author{
Christopher Smith
}

Abstract: This article summarises recent work on the engagement between art and archaeology, but seeks to embed this in a longer history of archaeology as a metaphor for other cultural and social practices, and at the same time to compare the ways in which archaeologists and other practitioners operate within the field of cultural production.

Keywords: Archaeology; art; knowledge; cultural production; agency; material turn

Affiliation: British School at Rome and University of St Andrews

Email address: cjs6@st-and.ac.uk

Land address: British School at Rome, Via Antonio Gramsci, 61, Roma, Italy 


\section{Beyond metaphor: archaeology as a social and artistic practice}

Christopher Smith

\section{Introduction}

Within the context of a conference on ways in which knowledge is constructed, the concept of archaeology has a profound metaphorical significance. It has been so since long before Foucault's brilliant use of the notion to dig down through the layers of the social and political contingencies of what we think we know, and if anything has become even more entangled. It is not uncommon for us to speak of archaeologies of emotion, archaeologies of sentiment, archaeologies of knowledge, all implying that archaeology as a method has relevance far beyond the site, and that what is buried is what is most significant (Thomas 2004, 149-170). However familiar we all are with the metaphor, and despite the acute awareness which archaeologists have of the socially embedded nature of their interpretations, it is still relatively rare for archaeology as a discipline to be looked at from the point of view of its own contextualised production of knowledge to examine how the metaphor of archaeology apples to archaeology as a practice.

This paper seeks to look at archaeology as a social and indeed artistic practice, and by so doing to expose it as part of a discourse of engagement with past and present which is in many ways as interesting as the objects and practices it uncovers. It is a very partial view of a complex discipline, and one which many archaeologists might not find describes their practice, but the anthropology of academic behaviour is an increasingly intriguing field of study, and one which merits attention in part because a critical approach to the manner in which we represent our activity may be a way of refining the arguments which defend our disciplines.

\section{The archaeology of archaeology as knowledge}

Many disciplines have had to confront the subjectivity of their findings. For some disciplines this has been challenging but cathartic. Historical disciplines have arguably been strengthened by debates, sometimes fierce, over what objective discoveries they can make and whether there are really the most interesting aspects of their intellectual work. Hayden White's explosion of the idea that texts could be treated as straightforward evidence, without reference to their rhetorical content and essential distortions, came as more of a challenge to historians than it perhaps should have done, but it coincided with the wave of thought, largely emanating from French scholars such as Derrida, which seemed to lay all notions of 'truth' under siege (Jenkins 1991, 1995, 2009).

For historians, the classic definition by Ranke of history as a presentation of the facts - wie es eigentlich gewesen - is now more or less abandoned. There are still 
skirmishes along the boundaries, but the discipline seems more at peace, more comfortable with the notion that the recovery of the perception or presentation of reality has its own value. It is also a discipline which has embraced with enthusiasm the popular media of television and books for general readership, often foregrounding personal interpretation and the role of the historian. History as a discipline has long flirted with its capacity to be popular, and the selfconsciousness which emerged from the history wars of the later twentieth century has made it more at ease with its role in shaping public opinion. (de Groot 2009; Korte, Paletschek 2014).

For archaeology, the subjectivity versus objectivity argument is slightly differently placed. In the same way that history professionalised its discipline in the late 19th and 20th centuries, so archaeology sought in a highly determined fashion to shake off the sense of itself as antiquarianism, a gentlemanly distraction driven by the interest in collecting. This evinced itself in many ways - larger sites, bigger teams (as if the size of the operation attested to the professionalism of the process), slower digs - but above all, by the increasingly conscious application of scientific methodologies and approaches. (Piggott 1989; Thomas 2004; Trigger 2006). The public face of archaeology tends to be around the process, or about the object of discovery.

Part of this is due to the great advances which science has made - geophysical investigation of subsoil structures, analysis of botanical and skeletal data, and carbon dating are just three examples of techniques which have given precision, or opened up entirely new areas of study, which were simply unavailable to previous generations. However, there was and is a political edge to this, and it was clearly the driver behind a clear push in American archaeology towards the business of counting things.

New or processual archaeology, as it is now called, emerged at the end of the 1950s for many reasons, but one was certainly a desire to place it on a par with sciences, and especially in America, where already in the 1960s and 1970s it was clear that research funding was going to be focused on disciplines where objectivity could be claimed. Most archaeology in America sat alongside anthropology not history; and much American anthropology was moving towards science and social science (Patterson 1986, 1995, 2003). Old art historical analysis was being left behind in favour of the collection of large amounts of data. Processual archaeology sought to find material correlates for largescale social change, and underlying this was a desire to find objective measures and to escape bias. Counting flints looked objective, scientific and worthy of funding in a newly competitive world.

Science also held out the attractive option of appearing to escape from the dangers of political entanglement into the safety of numerical neutrality. Archaeology has a dark history as a discipline, owing to its appropriation in arguments about origins, and racial superiority, which most notoriously led to claims about the Aryan roots of western civilisation deployed by Nazi propaganda (Kohl and Fawcett 1995; Gosden 2006). As Thomas put it, broadly speaking the rise of nationalism in Europe coincided with the transformation of antiquarianism into archaeology (Thomas $2004,109)$. There also seemed to be an innate bias in the evidence, which had tended 
to tell us far more about elites, and often about men. Again, the scientific approach offered a corrective by seeming to focus only on what could be counted. Lewis Binford, one of the giants of processualism, called this approach middle range theory. He looked at observable patterns of use of material in contemporary society, counted material in archaeological contexts and assumed the secure inference from current to past practice could lead to irrefutable deductions of behaviour. Easy as it is to show the flaws in this argument (and underplay the huge step forward it actually represented), at the time it was a powerful mechanism for giving archaeology a pass into the world of science (Raab and Goodyear 1984; Thomas 2004). In the next section we shall see another, older part of archaeology's own disciplinary stratigraphy.

\section{Archaeology and the discovery of self}

Imagine that an explorer arrives in a little-known region where his interest is aroused by an expanse of ruins, with remains of walls, fragments of columns, and tablets with half-effaced and unreadable inscriptions ... He may have brought picks, shovels and spades with him, and he may set the inhabitants to work with these implements. Together with them he may start upon the ruins, clear away the rubbish, and, beginning from the visible remains, uncover what is buried. (Freud et al., 2001)

The shift from antiquarianism to archaeology has often been studied (Piggott 1989; Marchand 2007), and the metaphorical significance of the process of digging down has been remarked on before. In the late nineteenth century, archaeology developed contemporaneously with the concepts of the painstaking discovery of the past and the emergence of a new concentration on memory (Matsuda 1996). The idea of the steady accretion of layers of history, and the potential to strip them back to something more original, was highly resonant, and the obvious parallel is with Freud, (Schorske 1991; Bowdler 1996; Armstrong 2005), but it is not the only one which could be deployed. Archaeology has been profoundly malleable as a symbolic exercise - its discoveries are laden with additional meaning, and its process can be compared to detective work (Shanks 1996) or performance (Shanks 2004, 2012). Importantly, at various points there has been a greater emphasis on archaeology as the recovery of fragments, rather than the whole picture. Archaeology recovers what remains, and is always partial, so the role of the fragment as a clue, as a sign, as a symbol of loss as much as survival, has been powerful - think of T. S. Eliot shoring up fragments against ruin.

The subjectivity and partiality of the archaeological enterprise, its methodological claim not to objective truth (the scientific claim in some form) but personal truth and internal discovery, is a shadow which accompanies the more scientific version of archaeology. This can be regarded as a threatening and paralysing division in the archaeological intellectual landscape, or as a productive tension, but it undeniably exists (Bradley 1993).

This methodological impulse was central for Foucault. Foucault saw in archaeology a metaphor for his own practice. He was fascinated by continuities and ruptures, by the way that the past continued to influence the present. It is not evident 
that he actually knew much about archaeology - Foucault did not spend his summers with a trowel in hand. It was for him a way of defining a methodology which was distinct from history and especially the history of ideas, which tended to prioritise (he believed) continuity, or structuralism which tended to imply fixed realities in tension with each other eternally. Foucault wanted a method which was interested in distinct layers, and which identified systems or epistemes. To give an example of how this helped his analysis, for Foucault madness was not a single concept, a given, but rather a constructed and highly contingent idea dependent on power structures at any given time. A change of structure, a change of the nature of power, could lead to a change in the definition of madness and therefore its treatment. An archaeology of knowledge looked at history as a way of understanding the processes that have led to what we are today.

So from Freud to Foucault we have a parallel history of archaeology in which the object of study is profoundly present and - pun intended - buried but of contemporary significance. Meanwhile, the scientific archaeologists might be thought to have been interested in the past as past, but they too played the game of modern relevance. The scientific method has no claim on innocence, and for the next part of this paper I want to explore two case studies in the use of archaeology in the service of different kinds of narratives.

\section{Queen Puabi and the murder at Mesopotamia}

The Institute for the Study of the Ancient World recently held an exhibition and published a catalogue on the 1920s and 1930s mission at Ur (southern Iraq), led by Leonard Woolley and Max Mallowan (whom Agatha Christie married), and the discovery of the royal tomb of Queen Puabi (Chi and Azara 2015).

Puabi was about 40 years old when she died. She stood just under five feet tall. Her name and title are known from a short inscription on one of three cylinder seals found on her person. Unusually for a woman in early Mesopotamia, there is no reference to her husband which has been taken to suggest that she was queen in her own right, some time before $2600 \mathrm{BC}$.

Her burial has two striking features. First she was accompanied in death by 52 attendants, who we now know had been ritually killed; the bodies had been positioned to imitate lying on each other's laps peacefully, sometimes placed in such a way as to hide damaged parts of the skulls. They may have been killed outside and then buried with Puabi. Second the grave was staggeringly rich, with gold, musical instruments, lapis lazuli and so forth - a truly royal site. The queen herself took to her grave a complex set of cosmetics and accoutrements, including a silver box with a scene of a lion killing a sheep or a goat, which contained kohl.

What the exhibition showed was how this led to a sequence of attempts to reconstruct the Mesopotamian aesthetic. Puabi was fascinating because she was a powerful woman, seemingly without a spouse. The original excavators, who were in explicit competition with Howard Carter (who, followed by newspapers and magazines, was revealing Tutankhamun in Egypt), rushed rapidly to narrative - was the queen herself murdered? What was her headdress really like? The determination 
to recover an individual, to assign to her a specific aesthetic, and to locate her within a concrete narrative, even if the events were four millennia ago, is striking. Archaeology is being deployed as part of a very clear narrative of sameness and connection - Mesopotamia is presented as an entirely comprehensible world.

Museums will always need to find ways to attract an audience and to use narrative, and the exhibition and catalogue bring out the changes in interpretation and emphasis over time, whilst the fascination with Puabi remained central, and inspirational. At the same time, the process of re-presenting Puabi within this selfreflexive matrix is itself characteristically postmodern. Whilst previous reconstructions had focused heavily on Puabi and her jewellery, the recent exhibition catalogue asked important questions about the meaning of the Mesopotamian aesthetic - the way the gold was chosen for its perpetual shininess and then repetitively hammered to be seamless, as though emphasising elements of continuity and maybe embedding them through the bodily processes of production by the goldsmiths.

What this entails is that the very act of deconstructing the highly individualised response to the queen herself as a sort of protostoric fashion icon remains itself part of a discourse of making the past enter into a debate with the present, but that the grounds of that debate and the locations have shifted and multiplied, as the curators clearly intended:

By exhibiting archaeological objects alongside archival material (letters, pictures, documentaries, notebooks and field records, press clippings and publications) and modern and contemporary works of art, we hope to convey that these things are not substantially different, but rather ontologically identical. Documents show how an archaeological find has been received and promoted, allow a find to become a work of art, illuminate the way an archaeological object has been transfigured into an aesthetic object, and stand as proof that this transubstantiation has taken place. In some cases, an archaeological find was accompanied by documents in a deliberate attempt to create a certain modern image of the object, with the desired result that the discovered object was actually accepted as a work of art. The ontological metamorphosis is complete when an artist interprets an archaeological item and produces his or her own work of art which is then either superficially or essentially similar to the ancient item. This process has enlarged the worlds of archaeology and aesthetics. It has also given new meaning to certain ancient objects, making them more complex and more intriguing, and breathing continuous life into them. (Chi and Azara 2015, 51)

\section{Crawford and the revenants in the landscape}

My second case study of the deployment of archaeology in contemporary broader discourse and art practice is taken from Kitty Hauser's superb explorations of the work of 0 . G. S. Crawford in aerial photography and in the ground breaking archaeological journal Antiquity, which Crawford founded in 1927 and edited until his death in 1957 (Hauser 2007, 2008). Hauser's biography of Crawford reveals a conflicted and difficult man, not really at home in any of his environments; a difficult colleague and a fierce editor (Wheeler 1958 for a contemporary view). Yet he was passionate about the value of the past, and his work and that of others, published in 
a form which was both scholarly but also reached a broader public, had an important impact at a time when external circumstances were encouraging a reflection on the potential loss of continuity and the threat to Britain, and a generation of writers and artists were responding with a revitalised sense of the value of English history (Harris 2010).

Aerial photography was born in a time of war, the first world war specifically, but its potential for archaeology was soon realised. Structures lying close to the surface, such as walls, affect the growth patterns of crops and grasses, so that at specific times they can become highly visible. Similarly, photographs taken in raking light will reveal shadows and marks on the landscape impossible to see at ground level. These are Hauser's shadow sites, the evanescent traces of the past, which sprang into view when after World War I pilots such as Crawford continued to fly and to photograph the British countryside. Aerial photography became - and to some extent remains a key part of the archaeological toolkit.

By the 1930s, Britain was facing war again, and over the next decades, across a variety of media, including more or less propagandistic films, the notion of Britain's deep past was to be explored. Revival of tradition, the holding on to certainty under the immense stress of war, and the appeal of elemental forces can be seen in many different forms. We have already mentioned Eliot, whose Anglo-Catholicism led to the Four Quartets, but whose earlier experimental Waste Land was hugely influential on an entire generation of poets. Among the most influential critics of the 1930s was Geoffrey Grigson, editor of the magazine New Verse; he would go on to be one of the founders of the ICA, to edit the About Britain series of regional guidebooks published to coincide with the Festival of Britain, and which followed previous series such as Britain in Pictures and the remarkable Shell Guides, to which we will return.

Grigson even more than Crawford is one of Hauser's heroes. His fascination with Antiquity, his belief in the redemptive fragment, and his friendship with many of the key figures of pre- and post-war art, such as Piper and Nash (Evans 2004; Spalding 2009; Jenkins 2010), make him a central figure in the demonstration of how landscape archaeology became a surprisingly resonant intellectual contribution. The rediscovery of the hidden past through photography, the careful identification of traces of walls, masonry, the very topography of the past, coupled with its perilous potential loss first in the tragedy of war and then in the seemingly unstoppable progress of modern urbanised England, all come together in narratives of deep history.

In art, Piper, Sutherland and Nash would all exploit elements of this to derive inspiration for landscapes which hint at the complexities beyond the more obvious Country Life and Picture Post celebrations of 'the land we are fighting for' and together with for instance Ravilious (Russell 2015) and writers such as Betjeman this was a generation which would construct the Shell Guides, one of the more remarkable attempts to define Britain and its enduring values whilst accommodating a newly mobile population which took to motor cars and trains to explore the nation.

We see here the use of archaeology as a redemptive preservation of the past giving roots and strength to present. Its complicated relationship to modernism rests 
in the sense that the past has more in common with reality, that myth is preferable to the shallow bourgeois platitudes of the industrial age (Thomas 2004). It is a sort of neoromanticism. By the time Crawford died in 1957, the urban changes which to some extent had caused such anxiety were in full flow. The professionalisation of archaeology in the increasingly modern and numerous universities ruptured the dialogue.

\section{Archaeology and art: further encounters}

However the encounter between archaeology and art did not end there. Neoromanticism is a forerunner of more modern Neopaganism, and there is a clear line between the fascination with the Wilmington giant and the Cerne Abbas figure, both of which Ravilious illustrated and who stand for the recovery of the ancient spirit of England (even if they were possibly much later) and the hugely successful Jed Butterworth play Jerusalem, with its unruly central figure who summons the collected history of England's spiritual past to resist the South Wiltshire authorities. Anarchism and folklore are a heady English brew (Bonnett 2010; Boll 2012; Winter and Keegan-Phipps 2013).

Stonehenge has been the most obvious focus of tension around the ownership and meaning of the ancient roots of Britain; the long sequence of problematic excavations, equinoctial riots, bad planning decisions, speculative interpretation and so forth have led it to be a highly troubled case study of where the past meets the present (Blain and Wallis 2007; Hill 2008; Wickstead 2014).

Another important and perhaps more positive area of encounter is land art. Richard Long is perhaps the most obvious British proponent, and Colin Renfrew has indicated his early fascination with his work which combines a personal engagement with the landscape through walking with recreations in various forms: stone, mud, earth (Renfrew 2003).

Bailey makes substantial claims for Long's influence:

As western interpretive archaeologists devoted great energies to the study of the landscape in the last decades of the twentieth century, they found inspiration in the work of Long, in the same way that archaeologists in the 1970s and 1980s found analogies in ethnoarchaeological investigation of non western communities of huntergatherers and simple agriculturalists. Long's work is complex and it is good to think with, whether those thoughts are about landscape or about traces and actions; archaeological practice and interpretation is much the better for his impact. (Bailey 2014)

The claim is for the artist's understanding of a landscape as somehow revelatory for an archaeologist. Perhaps this is another case of a 'stripping away' - the idea that the unmediated gaze of the artist can reveal what scholars fail to see; they study creativity but do not understand it.

This is not a straightforwardly obvious claim. Renfew's manifesto, Figuring It Out, What Are We? Where Do We Come From? The Parallel Visions of Artists and Archaeologists (Renfrew 2003), whose very title indicates an ambitious role for the combination of art and archaeology, laid out a striking claim for the potential 
relationship, and emerges from his own enjoyment of artists such as Long, Gormley and Parker (all of whom he introduced into collections in Jesus College, Cambridge). It is Renfrew's role as a prehistorian which perhaps allowed this elision to function more smoothly; absent the bundle of textual constraints which gets in the way of the span from classical to neo-classical art, the primitive is set free to be in conversation across time. The parallels between Cycladic Art and Brancusi, or land art and excavation, are to some extent obvious once demonstrated, but gaps remain.

One way of problematising this elision is to posit some essentialist difference

between

(post)modern and prehistoric humans. Weingarten wrote in her review of Renfrew,

In linking the 'freshness' of primitive and prehistoric art with contemporary art, Renfrew uncharacteristically overlooks an absolute scission between premodern and postmodern art: postmodern artists lack the embedded spiritual sense that had been integral to the art of all other periods and peoples. There is now no complex system of meaning in which art plays a role. There is no underlying story. One can only grasp the meaning of works of art from an earlier time by reconstituting as much of their system of meanings as possible, which remains, in part, the archaeologist's job. Otherwise, our relationship to prehistoric art is altogether external. (Weingarten 2005)

Another approach which opens up the problem is offered by Steve Mithen, who started his career as an artist at the Slade before becoming a notable prehistorian. He posits an essential difference between the responsibility of the observer: ' ... whereas "figuring it out" is an obligation for an archaeologist when faced with a prehistoric monument (or any assemblage of archaeological evidence), there is no such obligation when viewing a work of contemporary art' (Mithen 2004). Art is merely one of many helpful heuristic tools from which inspiration may come.

It is interesting in this context to see how the British Museum determinedly insisted that Ice Age material production could be characterised as art, arguing that art and the emergence of the modern mind were inextricably linked, and illustrated this with contemporary works such as Picasso's image of a bull's head made of bicycle parts, or representations of women by Matisse, Freud and Quinn (Cook 2013; Jones 2014).

The attempt to recover the cognitive nature of activity preserved in the archaeological record, a process especially associated with Renfrew, has drawn attention to the intention behind acts of creation, thereby liberating archaeologists from regarding the archaeological record is simply a matter of data. Archaeologists now find artists potentially instructive and in a privileged relationship, rather than Mithen's more neutral characterization; there is a reversal of influence.

Recently art and archaeology have become even more closely intertwined, as shown by Russell and Cochrane (2014). In the Sixth World Archaeology conference, from which this edited volume emerged, several artistic interventions were deliberately staged, and were highly impactful: 'The artists drew attention to qualities of archaeological things often overshadowed by the need for scientific objectivity - fascination, confusion, delight, inspiration and flawed attempts to understand or share these responses' (Russell and Cochrane 2014, 71). Art as archaeology - the staged 'excavation' of Bacon's studio, the scattering of imitation 
ancient sculpture and tracking its subsequent distribution, or the discussion of Christine Finn's 'excavation' of her own home, and its conversion into part of the LeaveHome-Stay arts project, are all new ways of conceiving of an ever closer link between art and archaeology, far beyond the now increasingly common involvement of an artist as part of a dig. This has its most extreme proponent in the Tate Thames Dig by Mark Dion, a project from 1999in which Dion, advised by Renfrew, effectively mimicked an archaeological dig, performed a classificatory analysis, and displayed the finds in an old-fashioned mahogany cabinet in the Tate (Vilches 2007). This play between archaeology and performance was conceived as humorous and allusive, but it raises deeper questions about what 'real' archaeologists are really doing, and therefore what they are examining.

The most consistent exponent and practitioner of the linkage between art and archaeology has been Michael Shanks, who with Mike Pearson has staged a number of projects, interventions, theatrical events and exhibitions to draw more tightly the link between archaeology and performance (Shanks 2012) for a summary. An example is his work on archaeography which he explains as follows:

Photography - turning your relationship with something that interests you, is before you and the camera, into a form that you can take away and look at later, share with friends.

Archaeology - taking old things that interest you away from where they were found and turning them into an archive, a collection, that you can study, write about, and share.

Archaeography - giving visual, (photo)graphic form to such relationships with the remains of the past in a recognition that both archaeology and photography emerged at the same time and under the same interests in the modern world of the first half of the nineteenth century.(http://www.archaeographer.com/ accessed 28 March 2016)

There are two different lines of engagement which we can trace here. Whilst modernism and processual archaeology shared a view that the object stood for something else - whether that be the deeper structures of society or some more spiritual realm of thought - post-processualism and contemporary practice has become highly concerned with things and with materiality (Ingold 2007; Tilley 2007; Rea 2011). The material turn has brought a much closer concern with objects and their potential agency. How can we understand our relationship with the physical world, and its relationship to us?

The other is more genealogical perhaps, deriving from the emergence of the discipline of archaeology, from a more acute perception of its role within the generation of knowledge. The professionalisation of archaeology and its scientific claims nevertheless are based on a discipline which is essentially part of a set of nineteenth century approaches to the representation of the world from the reconstruction politics of the Crystal Palace show (Nichols 2015) to the pseudoscience of racial anthropology to the nationalist agendas of historiography (Kohl and Fawcett 1995); and (Bergstein 2010) makes further arguments for the relationship between photography, archaeology and psychoanalysis. So Shanks can draw his archaeographies to refer out to a number of allusions, to reflect the archaeological imagination, which itself reflects its own social and political context. 
In the next sections we will consider the role of the archaeologist in the field of cultural production, before turning back to the concept of the fragment and the way in which archaeology has begun to empower the object through its own critical theory.

\section{Archaeology as métier}

In an essay in 1999, Yannis Hamilakis insisted on the role of the archaeologist within the field of cultural production (a term which Bourdieu introduced (Bourdieu 1993)), arguing that it was no longer acceptable to use the argument that archaeologists protected or stewarded the past as an excuse to look past their role and responsibility in exploring and interrogating the links of knowledge with power (Hamilakis 1999). His case studies were the complex legacy of Manolis Andronikos, who discovered the tomb thought to be that of Philip II of Macedonia at Vergina, and Ian Hodder's excavation, then only just beginning, at Çatalhöyük, which had attracted substantial corporate funding (see http://www. catalhoyuk.com/ accessed 28 March 2016).

Hamilakis' essay reminds us that archaeology is highly political, and that it is also an intellectual exercise as well as a practical challenge. His claim for an exclusive set of responsibilities which accompany the work which archaeologists do in producing representations which contribute to the construction and establishment of 'regimes of truth' is somewhat different from Shanks' rather breezier assertion that

We are all archaeologists now - fascinated by what is left of the past, our own memories and experiences, recent times as much as the ruins of ancient civilisations - working on what remains, caring about the past with a view to the present and the future. (http://www. mshanks.com/michael-shanks/; cf. Shanks 2012)

The two positions do share a view that archaeology is not about the discovery or indeed the stewardship of the past, but about working on what remains. This puts much more emphasis on archaeology as an intellectual and philosophical engagement with the world, rather than a producer of new knowledge through continuous excavation. This undoubtedly has some connection with the restrictions on archaeological activity produced by the spiralling cost of projects, and by the increasing concerns over the cost of maintaining and conserving sites once dug; and the modern capacity to extract meaning from every element of an excavation has raised both sides of the equation. So archaeology was looking to find other ways of continuing its work, but the desire to achieve a new form of relevance was also significant in pushing archaeology towards an increasingly theoretical position.

Perhaps the most seminal text was Michael Shanks and Christopher Tilley's Reconstructing Archaeology: Theory and Practice, first published in 1987 (Shanks and Tilley 1993). It was a work of its time, when politics was visceral and divided, as they underlined themselves (Shanks and Tilley 1993, 29). The text was regarded as political and to a large extent it was, though more subtly perhaps than some critics thought. It is a highly rhetorical text - offputtingly theoretical at times, at other times 
unexpectedly direct, this book was as far away from the norms of its time as you could get. Faced with sentences such as

Drunk on Hempelian whisky and functionalist cognac the new archaeology has regressed to be able to see little more about the symbolic and social other than that which can be reduced to the effects of the technological and the economic, the initial rungs of Hawkes' ladder (1954) beyond which traditional archaeologists did not care to venture, except in rare moments of secondary speculation. (Shanks and Tilley 1993, 32)

those traditional archaeologists reacted badly, as Shanks and Tilly gleefully admitted in the second edition. 'Messianic propagandists purveying pretentious irrelevancies and extremist pedantry, playing sceptical and cant-like word-games, deliberately misrepresenting in fallacious, illogical and inconsistent rhetoric, verging on exuberant intellectual dishonesty. These are some reactions to our work ...' (Shanks and Tilley 1993, xix).

In many ways the book was deliberately provocative - the highly scholarly comparison of the design of British and Swedish beer cans, deploying a range of processual and art historical methods to relate style to underlying social and economic realities, medical concerns and ideological positions, is a tour de force, not least by focusing on the archaeologists' alleged beverage of choice at a time when it was still a somewhat male and macho subject.

This attempt to produce a critically self-conscious archaeology, one capable of commenting on the world, one deeply aware of its role within the field of cultural production, also took a hugely significant step by involving the world of the museum in what turned out to be a prophetic manifesto. Shanks and Tilley dissected the choices being made in archaeological museums and showed the ways in which they perpetuated or ruptured specific knowledge systems or epistemes, in a Foucauldian sense. Comparing the programme which Shanks and Tilly spelt out with contemporary museum practice is striking:

(1) Introduce political content into conventional displays - show how the past maybe manipulated and misrepresented for present purposes

(2) Break artefacts from fixed chronological narrative and from their original contexts and reassemble them with contemporary artefacts similarly decontextualised: juxtaposition, montage (a) as a means of drawing attention to and engaging with official cultural meaning of the artefact and effecting an ideological critique of commodification and (b) as a means of illustrating alternative (non-commodified) meanings.

(3) Supplement 'objective third person narrative' with exaggeration, irony, humour, absurdity as a means of stripping the self-evident meaning of the artefact of its power.

(4) Avoid permanent displays, emphasise authorship and changing perceptions of the artefactual past. 
(5) Encourage the use of artefacts of the past outside the institutional space of the museum. Allows community use of the museum artefacts, people constructing and presenting their own pasts in the museum (Shanks and Tilley 1993, 98-99).

Whilst no museum perhaps has been able to take all of these steps, the loosening of the strict norms which seemed to tie display into similar chronological or typological formats, and the increasing interest in curatorship as a skill in itself, has certainly allowed juxtaposition and the foregrounding of exhibition authorship. The Queen Puabi exhibition, with the combination of the finds, the excavation records and contemporary responses to the whole story is a good example of how this can be done. In a different direction, Robin Osborne has recently argued that small museums can make a striking difference in how one appreciates objects; the concentration on small samples, on historical collections, or on casts in some ways creates some of the unexpected transitions and contrasts Shanks and Tilly encouraged (Osborne 2015).

Arguably one group of people left out of this is the archaeologists themselves, especially the fieldworkers. The empowerment of the interpreter, at the lowest possible level, rather than simply the impresario site director, was something advocated by Ian Hodder, who spoke of the importance of operating 'at the trowel's edge' (Hodder 1999, 83). Yet this remains elusive, as was pointed out in a response by Cumberpatch and Thorpe (1998) on the constraints especially on rescue archaeology ('time pressure and financial constraints devised by those to whom archaeology is akin to the removal of toxic waste').

The very transience of this piece, a draft of an unfinished and abandoned paper started in 1997 and dating to 1998, existing now only in the internet, reveals something about the fragility of the process we have described here. Even when the archaeological site veers towards a piece of performance art, it is still not a democratic place. The focus of struggle shifts, somewhat as Laclau and Mouffe argued it would (Laclau and Mouffe 2001). The archaeologist is and remains part of her or his own field of cultural production, and that varies in its freedoms and restraint, and insofar as archaeology reflects its society, it participates in and contributes to its hegemonic discourses. The revolution of the past 30 years or so has liberated archaeology to be more than a processual science of counting, and to embrace its own creativity and that of others; but it still depends on the agency of the archaeologist and thus reproduces the dynamics of human interactions. In the last section we look at attempts to decentre the human if not from the act of excavation, then at least from the field of study.

\section{The fragment}

Archaeologists find bodies and things; beyond that there is interpretation. Once we accept that we are looking at fragments, and couple that with the material turn, then the object can become more significant and more vital even than the human that 
used it. This focus on the object, and on how we interact with objects, and how they shape our behaviours, is now a critical part of the archaeological discourse.

In a sense this is a plausible response to the massive predominance of objects over attestations of human intention. Archaeologists find potsherds by the thousand sometimes, but rarely the thoughts of the potter. Discussing what the potter meant as opposed to what the pot does may be therefore more attractive as a response to the evidence we have. The theoretical underpinnings arise from Alfred Gell's famous work Art and Agency (Gell 1998), and the most recent extension is Material Engagement Theory - the attempt to identify how objects work with and for us in our cognition. The questions have been set out as follows:

What do things do for the mind? How is human thought built into and executed through things? What is the role of the brain in our embodied engagements with things? What kind of relationships and what types of interactions can be used to describe the vital connections between brains, bodies and things? Are things component parts or external media of human cognition? (Malafouris and Renfrew 2010, 2; cf. Malafouris 2013)

This of course rests on our conception of mind. If we accept the concept of an extended mind or indeed body, where the physical human structure is not a final limit, then one can arrive at 'a cognitive landscape in which brains, bodies and things play equal roles in the drama of human cognitive becoming' (Malafouris 2013, 2). For many archaeologists the power of the body extends beyond the physical frame, through the symbolism of objects, dress, perfume and so forth which are reconstructed from the material record, or presupposed, and even extends after life, as distributed body parts or reburials maintain the notion of the person and their power after death. Clearly this is largely metaphorical, but the persistence of memorials in the archaeological discourse is testament to the desire to extend power beyond the life of an individual, a desire which of course is easily harnessed and manipulated for present concerns. Anyone who doubts the enduring significance of the body need only consider the recent saga of the discovery in a Leicester car park of the body of Richard III and its reburial. Headstones embody memory and social persona, as well as enacting their own permanence.

This touches on the kind of challenge which was explicit in this series of conferences, the extent to which external instruments are now intrinsic to cognitive functions - the memory hard drive to which we upload our digital lives for instance. And art has long focused attention on these problems - through immersive performance or through the centering of the object or decentering of the person. Yet again, in material engagement theory, or in Ian Hodder's very recent development of the concept of entanglement, it is in art and the negotiations around artistic production, that archaeologists are finding their most productive theoretical insights (Hodder 2012; 2016). At the basis of this work is a common interest in creativity the creativity that responds to materials, that thinks through materials, or that is inspired by materials, a creativity which is widely manifest not simply the province of the great artist. 
To some extent this can become effectively an almost everyday anonymous miracle. Maurice Bloch for instance argues that the concept of the artist is a highly westernised construct and that for most of history, creativity was unselfconscious and integrated with social values (Bloch 2014). The routine nature of making, and the intimate interactions between humans and things in repetitive actions allow for different models of making. As Reckwitz noted, 'Practice theory 'decentres' mind, texts and conversation. Simultaneously, it shifts bodily movements, things, practical knowledge and routine to the centre of its vocabulary (Reckwitz 2002, 259). The theory of the entanglement or engagement between humans and things depends on both active thoughtful interaction and routine re-enactment. If archaeology has become a sort of performance art, then one of its key objects of study now is the performance of creativity and the relationship between human and object, and the location of agency.

\section{Conclusion}

Archaeology obviously reflects its own circumstances, but more than that archaeology by necessity constructs a present which construes itself as historically rooted. The subjectivity / objectivity debate which was provoked for instance by Shanks and Tilly missed their more significant challenge that the object and the site are not the past, but are representations of it, and to a very large extent can be seen as contemporary works of land art since they are almost entirely contingent, however much they are planned, in the sorts of ways Cumberpatch and Reubens outlined. The nature of those representations are all to some extent somewhere on a line between fictional to mendacious, depending on how critical one wants to be, and on what use they are being put to. They are partial fragments, and come to be through the process of destruction. Archaeology remains a profoundly paradoxical performance.

Yet the recognition of this paradox is at the same time a way of re-locating archaeology within its field of cultural production. We have touched on various ways in which archaeology and art overlap and intersect, and there are many more examples which could brought to bear, but enough has perhaps been said top show that this is a relationship which has been mutually fruitful. The commonality between the two subjects has shifted - we have explored ways in which archaeology chimed with the spirit of the time, when it provided the material of art; archaeology as a subject of its own reflection where its production of representation comes under scrutiny; archaeology in and out of the museum; archaeology as a performance itself and archaeology inspired by art. Taken as a whole, we have argued that archaeology has to be set against other forms of cultural production, read as an extension of their reflection on the world, because its claims for objectivity are nothing other than selfplacement within competitive disciplinary discourses of authenticity. The most obvious way to unite art and archaeology is to see a common interest in the act of creation, which leaves behind nothing more than a fragment, of an object, of its chain of production, of its maker. Over time, archaeology and art have come closest perhaps in their recognition of their role in representing the world, and 
understanding materiality, and its manifold entanglements. Archaeology is coming closer to the metaphorical weight which Freud lent it over a century ago, an internal voyage, an affordance of our self-awareness.

\section{References}

Armstrong, R. H. 2005. A Compulsion for Antiquity: Freud and the Ancient World. Ithaca, NY: Cornell University Press.

Bailey, D. 2014. "Art//Archaeology//Art: Letting-Go Beyond." In Art and Archaeology: Collaborations, Conversations, edied by I. Russell, and A. Cochrane, 231-250. Criticisms. New York: Springer.

Bergstein, M. 2010. Mirrors of Memory: Freud, Photography, and the History of Art. Ithaca, NY: Cornell University Press.

Blain, J., and R. J. Wallis. 2007. Sacred Sites-contested Rites/Rights. Brighton: Sussex Academic Press.

Bloch, M. 2014. "Different Types of Creativity on the Two Sides of Shutters." In Pragmatics and Cognition, edited by L. Malafouris, C. Gosden, and K. A.Overmann (Special Issue of Creativity, Cognition and Material Culture 22(1)), 109-123.

Boll, S. 2012. "The Sacred Dragon in the Woods: on Jez Butterworth's Jerusalem." Forum, 14. http:// www.forumjournal.org/article/viewFile/633/918

Bonnett, A. 2010. Left in the Past: Radicalism and the Politics of Nostalgia. London:

Continuum.

Bourdieu, P. 1993. The Field of Cultural Oroduction: Essays on Art and Literature. Translated by R. Johnson. London: Polity Press.

Bowdler, S. 1996. "Freud and Archaeology." Anthropological Forum 7 (3): 419-438.

Bradley, R. 1993. "Archaeology: The Loss of Nerve." In Archaeological Theory: Who sets the Agenda? edited by R. Bradley, 131-133. Cambridge: Cambridge University Press.

Chi, J., and P. Azara. 2015. From Ancient to Modern: Archaeology and Aesthetics. Princeton, NJ:

Institute for the Study of the Ancient World, Princeton University Press.

Cook, J. 2013. Ice Age Art: The Arrival of the Modern Mind. London: British Museum.

Cumberpatch, C., and R. Thorpe. 1998. "Some Notes Towards a Characterisation of Archaeology as a Social Practice." Retrieved from https://www.academia.edu/207515/Some_notes_towards_a_ characterisation_of_archaeology_as_a_social_practice.

Evans, C. 2004. "Unearthing Displacement. Surrealism and the "Archaeology" of Paul Nash.' In Substance, Memory, Display: Archaeology and Art, edited by C. Renfrew, C. Gosden, and E. deMarrais, 103-117. Cambridge: McDonald Institute Monographs.

Freud, S., J. Strachey, A. Freud, A. Strachey, and A. Tyson. 2001. The Standard Edition of the Complete Psychological Works of Sigmund Freud, (1893-1899), Vol. 3. London: Vintage; Hogart Press; The Institute of Psycho-Analysis.

Gell, A. 1998. Art and Agency: An Anthropological Theory. Oxford: Oxford University Press.

Gosden, C. 2006. Race, Racism and Archaeology. Abingdon: Routledge.

de Groot, J. 2009. Consuming History: Historians and Heritage in Contemporary Popular Culture. London: Routledge.

Hamilakis, Y. 1999. "La trahison des archeologues? Archaeological practice as intellectual activity in postmodernity." Journal of Mediterranean Archaeology 6 (1): 60-79.

Harris, A. 2010. Romantic Moderns: English Writers, Artists and the Imagination from Virginia Woolf to John Piper. London: Thames \& Hudson. 
Hauser, K. 2007. Shadow Sites: Photography, Archaeology, and the British Landscape, 19271955. Oxford: Oxford University Press.

Hauser, K. 2008. Bloody Old Britain: O.G.S. Crawford and the Archaeology of Modern Life. London: Granta Books.

Hawkes, C. 1954. "Archaeological Theory and Method: Some Suggestions from the Old World." American Anthropologist 56 (2): 155-168.

Hill, R. 2008. Stonehenge. London: Profile.

Hodder, I. 1999. The Archaeological Process: An Introduction. Oxford, MA: Blackwell.

Hodder, I. 2012. Entangled: An Archaeology of the Relationships between Humans and Things. Malden, MA: Wiley-Blackwell.

Hodder, I. 2016. Studies in Human Entanglement. Accessed from http://www.ianhodder.com/ books/studies-human-thing-entanglement.

Ingold, T. 2007. "Materials against Materiality.” Archaeological Dialogues 14 (1): 1-16.

Jenkins, K. 1991. Re-thinking History. London: Routledge.

Jenkins, K. 1995. On "What is History?": From Carr and Elton to Rorty and White. London: Routledge.

Jenkins, K. 2009. At the Limits of History: Essays on Theory and Practice. London: Routledge. Jenkins, D. F. 2010. Paul Nash: The Elements. London: Scala.

Jones, M. A. 2014. "The Cave and the Mind: Towards a Sculptural and Experimental Approach to Upper Palaeolithic Art." In Russell and Cochrane (eds.), 21-34.

Kohl, P. L., and C. Fawcett, eds. 1995. Nationalism, Politics and the Practice of Archaeology. Cambridge: Cambridge University Press.

Korte, B., and Paletschek, S. 2012. Popular History Now and Then: International Perspectives. Bielefeld: Transcript.

Laclau, E., and C. Mouffe. 2001. Hegemony and Socialist Strategy: Towards a Radical Democratic Politics. 2nd ed. London: Verso.

Malafouris, L. 2013. How Things Shape the Mind: A Theory of Material Engagement. Cambridge, MA: MIT Press.

Malafouris, L., and C. Renfrew. 2010. The Cognitive Life of Things: Recasting the Boundaries of the Mind. Cambridge: McDonald Institute for Archaeological Research.

Marchand, S. 2007. "From Antiquarian to Archaeologist? Adolf Furtwangler and the Problem of 'Modern Classical Archaeology'." In Momigliano and Antiquarianism: Foundations of the Modern Cultural Sciences, edited by Peter N. Miller, 248-285. Toronto: University of Toronto

Press.

Matsuda, M. K. 1996. The Memory of the Modern. Oxford: Oxford University Press.

Mithen, S. J. 2004. “Contemporary Western Art and Archaeology.” In Substance, Memory, Display: Archaeology and Art. McDonald Institute for Archaeological Research, edited by C. Renfrew, E. DeMarrais, and C. Gosden, 153-168. Cambridge: Cambridge University Press.

Nichols, K. 2015. Greece and Rome at the Crystal Palace: Classical Sculpture and Modern Britain, 1854-1936. Oxford: Oxford University Press.

Osborne, R. 2015. "De-contextualising and Re-contextualising: Why Mediterranean Archaeology Needs to Get out of the Trench and Back into the Museum." Journal of Mediterranean Archaeology 28 (2): 241-261.

Patterson, T. C. 1986. "The Last Sixty Years: Toward a Social History of Americanist Archeology in the United States." American Anthropologist 88 (1): 7-26.

Patterson, T. C. 1995. Toward a Social History of Archaeology in the United States. Fort Worth: Harcourt Brace College Publishers.

Patterson, T. C. 2003. A Social History of Anthropology in the United States. London: Bloomsbury Academic. 
Piggott, S. 1989. Ancient Britons and the Antiquarian Imagination: Ideas from the Renaissance to the Regency. London: Thames \& Hudson.

Raab, L. M., and A. C. Goodyear. 1984. "Middle-Range Theory in Archaeology: A Critical Review of Origins and Applications." American Antiquity 49 (2): 255-268.

Rea, W. 2011. "Archaeology, Photography, Sculpture: Correspondence and Mediations in the 19th Century and Beyond." In Sculpture and Archaeology, edited by P. J. Bonaventura, and A. Jones, 19-30. London: Routledge.

Reckwitz, A. 2002. "Toward a Theory of Social Practices: A Development in Culturalist Theorizing." European Journal of Social Theory 5: 243-263.

Renfrew, C. 2003. Figuring It Out: What Are We? Where Do We Come from? The Parallel Vision of Artists and Archaeologists. London: Thames \& Hudson.

Russell, J. 2015. Ravilious. London: Philip Wilson.

Russell, I., and A. Cochrane, eds. 2014. Art and Archaeology: Collaborations, Conversations, Criticisms. New York: Springer.

Schorske, C. E. 1991. "Freud: The Psychoarcheology of Civilizations." In The Cambridge Companion to Freud, edited by J. Neu, 8-24. Cambridge: Cambridge University Press.

Shanks, M. 1996. Classical Archaeology of Greece: Experiences of the Discipline. London:

Routledge.

Shanks, M. 2004. "Three Rooms: Archaeology and Performance." Journal of Social Archaeology 4

(2): 147-180.

Shanks, M. 2012. The Archaeological Imagination. Walnut Creek, CA: Left Coast Press.

Shanks, M., and C. Tilley. 1993. Re-Constructing Archaeology: Theory and Practice. 2nd ed. London: Routledge.

Spalding, F. 2009. John Piper, Myfanwy Piper: Lives in Art. Oxford: Oxford University Press.

Thomas, J. 2004. Archaeology and Modernity. London: Routledge.

Tilley, C. 2007. "Materiality in Materials.” Archaeological Dialogues 14 (1): 16-20.

Trigger, B. G. 2006. A History of Archaeological Thought. Cambridge: Cambridge University Press.

Vilches, F. 2007. The Art of Archaeology: Mark Dion and his Dig Projects. Journal of Social Archaeology 7 (2): 199-223.

Weingarten, J. 2005. "Rev. Colin Renfrew, Figuring it out, What Are We? Where Do We Come from? The Parallel Visions of Artists and Archaeologists." American Journal of Archaeology 109 (2): 287-289.

Wheeler, M. 1958. “Crawford and Antiquity.” Antiquity 32 (125): 3-4.

Wickstead, H. 2014. "Another Proof of the Preceding Theory: Film, Materialities and Stonehenge." In Russell and Cochrane (eds.) 2014, 99-114).

Winter, T., and S. Keegan-Phipps. 2013. Performing Englishness: Identity and Politics in a Contemporary Folk Resurgence. Manchester: Manchester University Press. 